\title{
Cutting-edge technologies for marine holobiont research: editorial comment on the highlighted article by J. Pamela Engelberts et al. 2021
}

\author{
Sandra Shumway ${ }^{1}$ \\ Published online: 8 November 2021 \\ ๑) The Author(s), under exclusive licence to Springer-Verlag GmbH Germany, part of Springer Nature 2021
}

Keywords Holobiont $\cdot$ Symbiosis $\cdot$ Coral reef

Microorganisms form symbiotic partnerships with the vast majority of animals living on earth and are increasingly recognised as being essential for overall ecosystem functioning (McFall-Ngai et al. 2013; Vanwonterghem and Webster 2020). Coral reefs in particular, one of the most productive and biodiverse ecosystems in the world, rely upon a multitude of symbiotic microbes to support the survival of habitat-forming taxa. The microbiomes of reef holobionts, including corals, sponges, ascidians, sea urchins, and algae, are thought to provide their host with nutrients, remove waste products, and produce secondary metabolites that aid in host defence (Bourne et al. 2016; Webster and Thomas 2016). A detailed understanding of the functional basis of the microbial symbioses that shape keystone reef taxa is, however, currently lacking and experimental validations of putative microbial functions are even more sparse.

The review "Integrating novel tools to elucidate the metabolic basis of microbial symbiosis in reef holobionts" by Engelberts et al. (2021) highlights key knowledge gaps regarding mechanisms of intra- and interspecific symbiotic interactions in reef species. The paper also provides a contemporary update to long-standing questions regarding the metabolic basis of reef symbioses and summarises recent methodological advancements that can be harnessed to address them. This review highlights the potential of techniques including metabolomics, Raman microspectroscopy, and CRISPR/Cas9-mediated genome editing for unravelling reef holobiont microbiome function, while describing challenges for their successful application. As such, this work provides a useful roadmap for researchers in the field of coral reef microbial symbiosis.

\section{References}

Bourne DG, Morrow KM, Webster NS (2016) Insights into the coral microbiome: underpinning the health and resilience of reef ecosystems. Annu Rev Microbiol 70:317-340

Engelberts JP, Robbins SJ, Damjanovic K, Webster NS (2021) Integrating novel tools to elucidate the metabolic basis of microbial symbiosis in reef holobionts. Mar Biol. https://doi.org/10.1007/ s00227-021-03952-6

McFall-Ngai M, Hadfield MG, Bosch TCG, Carey HV, DomazetLošo T, Douglas AE, Dubilier N, Eberl G, Fukami T, Gilbert SF, Hentschel U, King N, Kjelleberg S, Knoll AH, Kremer N, Mazmanian SK, Metcalf JL, Nealson K, Pierce NE, Rawls JF, Reid A, Ruby EG, Rumpho M, Sanders JG, Tautz D, Wernegreen JJ (2013) Animals in a bacterial world, a new imperative for the life sciences. Proc Natl Acad Sci 110:3229-3236. https://doi.org/ 10.1073/pnas. 1218525110
Sandra Shumway

sandra.shumway@uconn.edu

1 Department of Marine Sciences, University of Connecticut, 1080 Shennecossett Road, Groton, CT 06340, USA 
Vanwonterghem I, Webster NS (2020) Coral reef microorganisms in a changing climate. Iscience 23:100972

Webster NS, Thomas T (2016) The Sponge Hologenome. Mbio 7:e00135-e1116
Publisher's Note Springer Nature remains neutral with regard to jurisdictional claims in published maps and institutional affiliations. 